\title{
Has the Freedom of Information Act enhanced transparency and the free flow of information in Liberia?
}

Information Development

2018, Vol. 34(I) 20-30

(C) The Author(s) 2016

Reprints and permission:

sagepub.co.uk/journalsPermissions.nav

DOI: $10.1177 / 0266666916672717$

journals.sagepub.com/home/idv

(A)AGE

\author{
Proscovia Svärd \\ University of South Africa
}

\begin{abstract}
This article investigates if the adoption of the Liberian Freedom of Information (FOI) law 2010 has led to a transparent government and increased the free flow of government information. Freeing government information is expected to create transparent and accountable governments. It brings forth democratic and inclusive government institutions that work for the people. Inclusivity, transparency and accountability are expected to address sustainable development challenges and democracy deficits. Transparency and accountability can only be achieved through access to government information. The right to access government information is also included in the national constitution of Liberia. The citizens of Liberia in West Africa suffered from a protracted civil war between 1989-1996 and 1999-2003 respectively. These wars were partly caused by non-accountability of the governments, endemic corruption and the mismanagement of the countries' resources. Efforts are being made by the government with the help of the international community to embrace a new democratic dispensation. Liberia was also one of the first African countries to enact a Freedom of Information (FOI) Law that would enable Liberians to access government information.
\end{abstract}

\section{Keywords}

transparency, accountability, freedom of information, legislation, Liberia

Submitted: 20 April, 2016; Accepted: 13 September, 2016.

\section{Liberia has made some progress in the free flow of government information but government transparency is still poor and corrupt practices continue to flourish.}

\section{Introduction}

The article investigates whether the adoption of the Liberian Freedom of Information (FOI) Act in 2010 has delivered the expected results of a more transparent government and the free flow of government information to the citizens. Liberia in West Africa is transitioning from two decades of violent conflict that led to heinous and gruesome acts committed against humanity. The violent conflict was characterized by massive killings, displacement, property destruction, sexual violations, extra judicial killings, plunder and economic crimes since natural resources were exploited to finance armed conflicts in the country. Misrule, endemic corruption and the mismanagement of the country's resources have deprived many
Liberians of the dividends from its rich natural resources (Ballah and Abrokwaa, n.d.; McGovern, 2005; Small Arms Survey, 2011). Liberia is a resource-rich country with a river system that supports the cultivation of rubber, palm oil and tropical fruit plantations. The country has the richest timber resource on the African continent and also has the world's highest quality of iron ore and significant deposits of diamonds and gold (Rich and Warner, 2012). After such a traumatic past, in 2005 Liberia

Corresponding author:

Proscovia Svärd, University of Södertörn, Stockholm. Tel. No. +46736507333.

Email: Proscovia.Svard@sh.se 
held what were referred to by the international community as free and fair elections. These elections ushered in the first female president on the African Continent, Ellen Johnson Sirleaf. She was re-elected in 2011 and was awarded a Nobel Prize for having ended the war. The Liberian government has worked together with the UN peace-keeping mission to bring about stability in the country (Small Arms Survey, 2011). In 2007, Radelet (2007) opined that Liberia's consolidation of peace hinged on rapid, inclusive and sustainable economic growth. Liberia is a country that has been grossly mismanaged for a period of 25 years and experienced a civil war that went on for 14 years.

Atoubi (2007) argued that corruption is one of the major problems that West African countries face since independence. It has contributed to the alienation of the people from those in power and hinders the fight against poverty. This in turn erodes the trust that people ought to have in government institutions. It further hinders good governance and democratic developments and affects the institutional capacity of governments to deliver services to their citizens. Atoubi (2007: 2) further posited, "The existence of widespread corruption, especially in societies beset by mass poverty and very high levels of unemployment, has a deeply corrosive effect on trust in government, and contributes to crime and political disorder." He was of the view that corruption plays a major role in fomenting and prolonging conflicts because of the grievances held by the people towards their leaders. Ellen Johnson Sirleaf acknowledged during a speech at the University of Ghana in 2010 that corruption undermines legitimacy and the effectiveness of state institutions hence, compromising peace building. The president stated that: "In the context of Liberia, a wide range of distinct social problems - such as weak and dysfunctional government institutions, mismanagement of public assets, complex relationships between political actors and public economic assets, and postwar extra-legal networks - have all been subsumed under corruption" (Johnson, 2010: 15). Neuman (2002) also emphasized that corruption leads to unequal access to public services and justice, reduced investor confidence, continued poverty and violence.

Liberia's post-conflict governance challenges were highlighted in 2005 in an article commissioned by the United Nations and the World Bank entitled 'Liberia's Governance and Economic Management Assistance Programme (GEMAP)' (Dwan and Bailey, 2006) which explicitly stated that international partners were concerned about the economic governance of the country and hence the formation of the 'Governance and Economic Management Assistant Program'. This initiative was a response to corruption and the mismanagement of public funds. The focus of the initiative was on public finance management and accountability and included revenue collection, expenditure controls and government procurement and concession practices. This work led to the establishment of the Anti-Corruption Commission, because good economic governance was seen as crucial to Liberia's future stability. When President Ellen Johnson Sirleaf took over power in 2005, she vowed to deliver growth, development, reconciliation and transparency, especially in the extractive industries sector (Glencorse, 2013; Rich and Warner, 2012).

In order for the Liberian government to demonstrate its commitment to good governance, it enacted in 2010 a Freedom of Information Act that is supposed to promote the free flow of government information to the citizens (Centre for Media Studies and Peace Building, 2013). Freedom of expression and free access to information are cornerstones of modern democracies. It is internationally believed that transparent governments govern better. Transparency and accountability are meant to create governments that are legitimate and hence supported by the citizens (Gaventa and McGee, 2013). The term 'transparency' is closely connected to accountability because, through the information that is made available to the citizens, those in power are called upon to account for their actions (McGee et al., 2010). Florini (1999) contended that transparency is loosely defined and she attributes this looseness to the fact that it is used in different areas. In politics the term means providing information to the citizens to enable them to scrutinize the actions of the government. This is the meaning that this article espouses. She defined transparency as "the release of information by institutions that is relevant to evaluating those institutions" (Florini, 1999: 5). Though transparency is globally supported, it is opposed by those who are supposed to be scrutinized. However, since 1977 globalization has pushed the demand for increased transparency in many parts of the world. Accountability, on the other hand, is defined as "procedures requiring officials and those who seek to influence them to follow established rules defining acceptable processes and outcomes, and to demonstrate that they have followed those procedures" (Johnston, n.d.: 2).

When citizens have access to information they get empowered to interrogate their governments on the decisions made on their behalf. Bamgbose and Etim 
(2015: 1) argue that "Information is the stimulus of all the thoughts and actions of living creatures. No doubt, it is a prerequisite for the functioning of the modern society because success in every area of human endeavour is premised on its intelligent use." Democracy building requires knowledgeable citizens who can act on their rights. Access to information generates knowledge and knowledge is power. Governments are therefore encouraged to engage in the proactive disclosure of information in order to build trust. Open data increases transparency and also enhances participation and collaboration between the government and the citizens through the creation of new electronic services and policies (Organisation for Economic Co-operation and Development, 2016). In 2010 President Obama expressed the view that open economies, open societies and open governments are the strongest foundation for human progress (Manolea and Cretu, 2013). To address developmental and democratic challenges, transparency and accountability are seen as a solution. Transparency and accountability are achieved through an effective flow of information between the government and its citizens About 100 countries, of which 10 are in Africa, have adopted Freedom of Information (FOI) laws (Yong, 2004).

Article 15, Sections (b) and (c) of the Liberian constitution guarantees its citizens access to information. Section (b) states, "The right encompasses the right to hold opinions without interference and the right to knowledge. It includes freedom of speech and of the press, academic freedom to receive and impart knowledge and information and the right of libraries to make such knowledge available. It includes noninterference with the use of the mail, telephone and telegraph. It likewise includes the right to remain silent" and Section (c) states, "In pursuance of this right, there shall be no limitation on the public right to be informed about the government and its functionaries" (Liberian Government, n.d.: 5). Liberia was one of the first West African countries to enact the FOI Act. The Act was passed after several years of lobbying and advocacy by civil society groups. The Freedom of Information Act acknowledges that access to information is a fundamental right guaranteed by the country's constitution. Section 1.4 (b) states: "Everyone has a right of access to information generated, received and or held by public bodies, subject only to such limitations as are necessary and narrowly established for reason of an equally or more compelling public interest". Section 1.4 (c) of the Act emphasizes that "The right of access to information includes both (1) a right to request and receive information, and (2) an obligation on the part of public bodies and officials to disseminate essential information that the public would generally want to know, including their core functions and key activities" (Liberian Government, 2010: 3). The citizens of Liberia are free to request, receive, review, reproduce and retain records and documents held by public bodies and private entities that perform public functions or receive public funding (Liberian Government, 2010). In 2010 the President further issued an Executive Order to protect whistleblowers (IBIS, 2014). Transparent governments are expected to harness sustainable development and democracy. Gongloe (2012) contended that a government that restricts the free flow of information threatens its national security. This is because where there is lack of information citizens depend on rumours rather than facts, which can incite violence should there be dissatisfaction with the government.

Another cornerstone of democracy lies in the transparency of the processes of political decision-making and their implementation. To achieve transparency and accountability in government institutions, certain structures need to be put in place. What is often left out in the discussions on transparency and accountability is the importance of a well-developed information management infrastructure to facilitate the documentation of government actions. This infrastructure should have information systems that are reliable and that enable the effective creation, capture, organization, management, dissemination and preservation for re-use of government information (Svärd, 2014). Robust information records management systems are crucial to accountability and transparency and also protect the citizens' rights (Ngoepe, 2004).

\section{Research problem}

The adoption of Freedom of Information (FOI) laws is expected to lead to transparent, accountable and inclusive governments with well-functioning institutions. However, Martini (2014) argued that despite this consensus about FOI laws, there is very little empirical evidence about their impact. Authors such as Banisar (2006) further posited that in order for true transparency to be achieved, governments need to do more than just enacting Freedom of Information laws. This article therefore investigates if, in the Liberian case, the FOI Act has created a more 
transparent government and whether government information is availed to the citizens as prescribed by the Act. The paper therefore aims to answer the following research questions:

Has the adoption of the Liberian Freedom of Information Act of 2010 resulted in a more transparent government; and has it promoted the free flow of government information to the citizens?

\section{Literature review}

In an article by Randall, Kpargoi and Pulano (n.d.), the authors argued that lack of information access legislation hindered the coverage of corrupt practices and participation of the citizens of Liberia in governance issues. Joseph (2006) argued that efforts had been made to enact the FOI Act in Liberia in 2005, but they did not materialize. However, with a democratically elected government and a strong political will to carry out democratic reforms, prospects of enacting and implementing the FOI Act increased. Strong collaboration among media practitioners, civil society actors and rights activists pushed for the enactment of the FOI Act. He highlighted the need for print and electronic media platforms to continue to be used in the sensitization of the public about the enactment and implementation of the FOI Act. There were, however, challenges and hindrances that needed to be addressed and these included:

- the fact that democratic norms and principles were still not firmly rooted in the psyche of the people

- inadequate education and awareness about the Act

- reluctance by some decision-makers in government to break the taboo of non-disclosure

- a climate of hostility between the government and the independent media

- weak infrastructure, bureaucratic delays and ill-trained personnel in government agencies

- wrongful application of the clause

- economic constraints facing the media and the public.

He expressed the fear that the above challenges and hindrances could forestall the passage and implementation of the Liberian FOI Act (Joseph, 2006).

The Carter Center's Global Access to Information Program supported the passage of the Liberia FOI law and continues to support its implementation. It has engaged in the following:

- provided technical assistance, capacity building, and advice to nine target ministries and agencies which serve as a vanguard for the rest of government

- provided specialized training for designated information officers

- supported improvements in records management

- assisted in the development of manuals and procedures for Accountability and Transparency Initiative (ATI) implementation efforts

- raised awareness of the value of ATI and specific responsibilities under the Liberian law

- helped establish the Information Offices with computers and equipment

- supported the selection process for a new Independent Information Commissioner (IIC) and assisted in the establishment of the IIC's office, policies, and procedures (The Carter Centre, n.d.).

The author has not been able to access any scientific articles that give a chronology of the developments that led to the establishment of the Liberian FOI Act. This also confirms scarcity of research on the issue.

\section{Method}

The researcher applied desk research and document analysis to pursue the research objective. Desk research involves collecting data from existing sources, organizing, sorting, analyzing and presentating from a researcher's own desk. This kind of reseach helps to examine existing literature and hence situates the study in the context of existing evidence. Document analysis entails a systematic evaluation of documents (Management Study Guide, n.d.). It requires the researcher to examine and interpret documents that are relevant to the phenomenon being researched in order to gain an understanding and develop empirical knowledge. When conducting document analysis the researcher therefore depends on previous studies as sources of data and description and interpretation of data is the basis of analysis (Bowen, 2009).

\section{Research findings \\ Liberia's post-conflict challenges}

Rich and Warner (2012) claimed that the Liberian natural resources sector faced challenges of dubious 
contracting procedures where local politicians, ministers and government officials were suspected of collaborating with extractive companies to steal the proceeds from the sector. The Liberian Extractive Industries Transparency Initiative that came into being in 2009 requires all government agencies and extractive companies to document the payments they make to the government, review operating licences, and archive the documents and all the information generated as a result of the process. This information is expected to be put in the public domain. However, systemic corruption continues to thrive and to debilitate government institutions. Extractive contracts are not fully monitored and enforced and personal agendas continue to be prioritized over public duties (Rich and Warner, 2012). Glencorse (2013) also confirmed that the government continues to illegally issue permits to extractive companies that exploit the country's natural resources, such as logging. The Liberian government has undertaken measures to improve governance issues. Several Acts have been enacted, such as the FOI Act, the Anti-Corruption Commission Act, the Public Procurement and Concession Act, the Public Financial Management Act, the Extractive Industries Transparency Act, and the Revised General Auditing Commission Act. The country is also a member of the Open Governance Partnership (OGP) and the Extractive Industry Transparency Initiatives (Liberian Government, 2013). The President has further undertaken reforms to clean up among corrupt officials and a number of institutions have been established to enhance transparency and accountability. The reforms have entailed establishing institutions such as the Liberia Anti-Corruption Commission, the General Auditing Commission and the Public Procurement and Concessions Commission.

Despite these discernible efforts, Glencorse (2013) postulated that Liberia is far from a well-functioning society, since the government has failed to deliver the badly needed services of water, sanitation and electricity. Corruption remains endemic and is perpetuated by low salaries, lack of training and capacity, inefficient and cumbersome regulations that create incentives and opportunities for corruption in the public sector. A good number of Liberians are still in the grip of abject poverty (U4 Anti-Corruption Resource Centre, 2012). Liberia has a high rate of unemployment and continues to be ranked by Transparency International as one of the most corrupt countries in the world. The country continues to perpetuate a system of cronyism and nepotism, where private obligations are prioritized over public duties.

\section{The implementation of the Freedom of Information Act (FOI)}

Reeve (2011) stated that although the flow of government information has increased since the end of the wars, the majority of Liberians do not feel informed about events that take place in Liberia. However, they feel better informed at the community level. Liberia currently has a free media environment, which could be used to disseminate information to the masses; however, to access formal media, one needs purchasing power and an education. In order to promote information access, the government of Liberia took the following measures to implement the Act:

- appointedPublic Information Officers pursuant to the FOI Act to ensure effective implementation

- provided support to the Information Commission to ensure effective oversight of the FOI Act

- standardized all government websites to have them regularly updated with relevant information

- increased internal and external awareness on the FOI Act of 2010

- adopted a standardized FOI implementation procedure and policy.

However, in an Internet posting, Teemu (2013) argued that, despite the reforms that the Liberian president has undertaken, accessing government information is still problematic and the implementation of the FOI Act is unsatisfactory. The posting suggested that access could be enhanced through the following:

1. one citizen-centric place for knowledge that answers questions ordinary citizens have

2. an open data portal, that gathers data assets (like statistics, demographic information, geographic information) in one place.

Teemu also warned that the fact that most Liberians are not connected to the Internet should be taken into consideration when planning for dissemination of government information. The posting suggested the use of print media, radio, talk shows and chalkboards to disseminate information to communities that lack Internet connectivity. The Center for Media Studies 
and Peace Building carried out a pilot study entitled 'Post Enactment Implementation Regime and the Liberian Freedom of Information Act 2010' and also revealed that responses to information requests are abysmally low. The Centre lamented the lack of a tracking system to register both written and oral requests for information and the fact that some ministries had not appointed the information officers who were supposed to be the intermediaries between the citizens and government ministries (Center for Media Studies and Peacebuilding, 2013). In 2014, the Liberia Media Centre made information requests to 45 government agencies as per the FOI Act, and only 13 percent of the agencies honoured these requests (Mayue and Kpargoi, n.d.). Kpargoi, who is a lawyer, activist, journalist and an officer in charge of the Liberia Media Center, also argued that despite the FOI Act, government transparency is still distant and implementation has been poor. He postulated that

Five years down the line though, the freedom of information law can hardly be seen as an instrument that has brought more openness to the governance process of Liberia. In 2012 the Center for Media Studies and Peacebuilding filed a complaint with Liberia's Independent Information Commission to compel the country's anti-corruption body to turn over asset declaration filings of government officials. Three years later however, the complaint remains stuck in the country's judicial system after the anti-corruption body appealed the information commissioner's decision to make the asset declarations public (Kpargoi, 2015: 1).

Treisman (2014) also confirmed that enacting the Act has led to an increase in the flow of government information to the citizens, but that it is still a timeconsuming process and a challenge. Treisman further postulated that in order to make use of the information, one needs to be able to interpret it. Joseph (2014) stated that public awareness campaigns had, to a certain degree, managed to create awareness of the people's right to access government information. He lamented, however, that the numbers of honoured information requests were still low. He also observed that the FOI Act had brought about positive developments such as information regarding access to development funds by some of the poor communities. He confirmed, however, that FOI Act campaigners were faced with the challenges of lack of resources and commitment from the side of the politicians.

The Accountability Lab and iLab Liberia are collaborating with the Ministry of Information, Cultural
Affairs and Tourism to create an open data hub and governmental portal. In order to bridge the digital and illiteracy divide, these two organisations are said to have endeavoured to make information available to the citizens using the chalkboard approach, where key information written in a local language, and pictures or diagrams are posted. ILab Liberia is described at its website as "a non-profit computer laboratory providing access to cutting-edge technology, expert IT assistance and a community leveraging technology for the good of Liberia." The organization is also mentioned in the Liberian OGP Action Plan for 2013 as a strategic partner in popularizing the FOI Act and making it accessible to as many Liberians as possible (ILab, 2015: 1). The Accountability Lab "catalyzes a new generation of active citizens and responsible leaders around the world. We train, mentor, and resource local change makers to strengthen systems of accountability and unleash positive social and economic change." This organization has offices in Washington, Nepal and Monrovia (Accountability Lab, 2016: 1).

During an event held at the Centre for International Media Assistance on the new UN Sustainable Development Goals, Kpargoi (2015) stated that he was astonished to hear Liberia mentioned as one of the fragile states that are promoting information access to harness good governance. He wondered whether Liberia impressed its international partners differently. A study conducted by the Carter Centre and Irish Aid confirmed that Liberian women did not have access to information. They were to use the results of the study to create solutions that would promote women's right to access information (The Carter Centre, 2014). Reeves (2011) claimed that ownership of radios, literacy and command of English media consumption in Liberia is disproportionately a male activity. It is confirmed by the Africa Freedom of Information Centre that the Liberian campaigners of the FOI Act have over the years faced challenges of lack of capacity and resources and fluctuating political will from the government. They recommended that the National Access to Information Act should continue to be a top priority for the government (Africa Freedom of Information Centre, 2014). The Carter Center carried out an assessment of the FOI Act implementation in Liberia and concluded that there were still impediments to information access. These impediments included insufficient government leadership, lack of guidelines for access, agency leadership that hindered information officers from 
responding to information requests, lack of capacity in the ministries and agencies and failure to follow statutory requirements when honouring information requests (The Carter Centre, 2016).

\section{Adhering to international standards}

To demonstrate its commitment to the transparency endeavour, the Liberian government signed a letter of intent in 2011 to join the Open Governance Partnership initiative. To increase transparency and trust in government institutions the government undertook reform initiatives such as access to public information, open and competitive and contracting process, open budget process and extractive industries transparency. According to the Liberian Open Government Partnership Action Plan for 2013, the citizens are increasingly participating in decision-making processes at several levels. Public officials are also expected to exhibit a high degree of honesty through the declaration of their assets prior to assuming government positions (Liberian Government, 2013). Liberia is also a signatory to the Extractive Industries Transparency Initiative (EITI) and was the first West African country to pass its validation. Endorsed by the United Nations General Assembly, the World Bank and the Group of Twenty, the EITI was created in 2002 to strengthen transparency in the extractive industries through the publication of government revenues from natural resources such as oil, gas and mining. Although the reforms that have so far been instituted by the Liberian President have included the establishment of domestic oversight institutions, Glencorse (2013) argued that they still lack the powers and resources to satisfactorily pursue their duties.

\section{Discussion}

Globally, the call for transparent, accountable and inclusive governments is high on the agenda. Global initiatives have been established to promote transparent, accountable and more inclusive governments (Florini, 2007; Manolea and Cretu, 2013; McGee et al., 2010). Governments are encouraged to release their information flows in order to empower the citizenry with knowledge. It is believed that through access to government information the citizens can have a well-informed ground upon which they can stand to interrogate their governments about the decisions they make on their behalf. They can also participate in government policy-making processes. Enacting Freedom of Information laws is supposed to solve the problems related to sustainable development and democracy deficits (McGee et al., 2010). Through access to reliable information, government institutions can be scrutinized and malpractices exposed. This way, the corruption that is depriving many African citizens of development would be fought (Atoubi, 2007). Global initiatives that push for transparent, accountable and inclusive government have been established because the domestic audit institutions are deemed corrupt and therefore insufficient to deliver the checks and balances required to maintain a democratic society (Florini, 2007).

Some of the reviewed authors (Banisar, 2006; Martini, 2014) argued that although countries are adopting FOI laws, there is still lack of empirical evidence regarding their impact and that governments need to do more than merely adopting these Acts. This article therefore set out to establish if the adoption of the Liberian Freedom of Information (FOI) Act of 2010 has resulted in a more transparent government and if it has promoted the free flow of government information to the citizens. The Liberian government has undertaken certain reforms to create a more transparent government and to fight corruption. Some progress is also being made regarding the free flow of government information but government transparency is still said to be poor and corrupt practices continue to flourish. It is also claimed in the reviewed literature that through FOI some rural communities, can now access government development funds (Joseph, 2014). There are therefore still challenges that ought to be addressed and these include Liberian women's lack of access to information, low literacy levels which make it difficult for many citizens to make use of the information they access to their own advantage, lack of the purchasing power to access formal media, lack of resources and the political will to undertake a satisfactory implementation of the FOI Act, lack of Internet connectivity which requires alternative ways of disseminating information to the public like, for example, the chalkboard solution, lack of an information management infrastructure, lack of robust reporting to the public on the revenues from the extractive industry and hence the issue of corruption, which is still rampant (Joseph, 2006; Reeve, 2011; Teemu, 2013; The Carter Centre, 2014; U4 AntiCorruption Resource Centre, 2012).

It is not enough to create international initiatives that require governments to submit annual reports that do not reflect the reality on the ground. Glencorse (2013), for example, argued that the Liberian 
government continues to pursue dubious contracting procedures in the extractive industry that enrich the political elite, yet some literature confirmed that Liberia was the first country to pass the validation procedure of the EITI. The fight against corruption in Liberia will require social responsibility if it is to be uprooted, since it is systemic and endemic (Johnson, 2010; U4 Anti-Corruption Resource Centre, 2012). The reforms implemented by the President will only be effective if the politicians and the citizens work together to bring about inclusive, transparent and accountable government institutions. The civil society organizations continue to engage in the implementation of FOI but they will need committed political support (Joseph, 2006; Mayue and Kpargoi, n.d.; The Carter Centre, 2014).

There are significant barriers to information access in post-conflict societies. Societies that have been suppressed for decades lose the inate curiosity to demand information. High illiteracy levels also exacerbate the situation. Women are singled out in the reviewed literature as a group that is underprivileged because they lack education, technology and skills to access government information (Randall et al., n.d.; Reeve, 2011; The Carter Centre, 2014). The issue of women's lack of access to government information is being addressed by the government. However, high levels of illiteracy should not hinder the dissemination of public information since official information can always be translated into local languages, written on chalkboards as suggested in the literature or broadcast over radio and television (Teemu, 2013). Harnessing technology such as the use of affordable mobile phones to disseminate information is crucial.

It takes time to uproot the culture of impunity and non-accountability and also requires long term investments and commitment from the governments' side (Joseph, 2006). Understanding the inherent complexities of post-conflict societies is key to promoting access to information and accountability. To fight impunity and corrupt practices, robust information systems need to maintain logs of the transactions carried out by government offices. Promoting transparency and accountability requires investigative journalism to expose the corrupt practices of government officials. Transparency and accountability hinge on how well documented government processes are and how trustworthy and complete the documentation created under the process is. This requires an information infrastructure that can facilitate the effective creation, capture, organization and dissemination and re-use of government information.

\section{Conclusion}

Though Liberia is making some progress in creating transparent government processes and freeing government information, more needs to be done to achieve true transparency, which would expose corruption. Creating an information-aware society requires sensitization of the citizens about the right to access government information. Thus, a robust information management infrastructure and good information and records management practices are prerequisites that maintain the open structure of government institutions. If information access is to be promoted, there has to be committed political will to avail information to the citizens. Therefore, appropriate procedures, processes and systems are considered necessary to provide and maintain trustworthy information. Given the low levels of literacy in the country, it is of paramount importance to find alternative ways of disseminating information to the public. There is a clear correlation between good information management practices and good governance. Investments should therefore be made in information management courses at the tertiary level in order to promote an understanding of the role of information in enhancing democracy. This would empower the general public to scrutinize how their governments manage the public goods meant for the country's development.

\section{References}

Accountability Lab (2016) An incubator for young people to transform their societies. Available at: http://liveaccountability-lab.pantheonsite.io/ (accessed 23 April 2016).

Africa Freedom of Information Centre (2014) State of right to information in Africa. Available at: http://www.afri cafoicentre .org/index.php/reports-publications/139state-of-right-to-information-in-africa-report-2014? path $=($ accessed 10 September 2016).

Atoubi SM (2007) Corruption and state instability in West Africa: An examination of policy options. KAIPTC Occasional Paper (No. 21). Available at: http://www .kaiptc.org/Publications/Occasional-Papers/Documents/ no_21.aspx (accessed 1 April 2016).

Ballah $\mathrm{H}$ and Abrokwaa CK (n.d.) Ethnicity, politics and social conflict: The quest for peace in Liberia. Available at: http://www.gradschool.psu.edu/diversity/menair/ papers2003/ballahpdf/ (accessed 1 September 2016).

Bamgbose OJ and Etim IA (2015) Accessing government information in Africa through the Right to Know: the 
role of the library. Available at: http://library.ifla.org/ 1221/1/114-bamgbose-en.pdf (accessed 29 March 2016).

Banisar D (2006) Freedom of Information Around the World 2006. A global survey of access to government information laws. Available at: http://www.humanright sinitiative.org/programs/ai/rti/international/laws papers/intl/global_foi_survey_2006.pdf (accessed 20 March, 2016).

Bowen GA (2009) Document analysis as a qualitative research method. Qualitative Research Journal, 9:2: 27-40.

Center for Media Studies and Peacebuilding (2013) Freedom of information demand and supply compliance monitoring: A pilot study of post enactment implementation regime of the Liberian Freedom of Information Act 2010. Available at: https://www.ifex.org/liberia/ 2013/06/27/liberia_foi_report.pdf (accessed 4 September 20016).

Dwan R and Bailey L (2006) Liberia's Governance and Economic Management Assistance Programme (GEMAP). A joint review by the Department of Peacekeeping Operations' Peacekeeping Best Practices Section and the World Bank's Fragile States Group. Available at: http://siteresources.worldbank .org/INTLICUS/Resources/DPKOWBGEMAPFINAL .pdf (accessed 28 March 2016).

Florini A (1999) Does the invisible hand need a transparent glove? The politics of transparency. Available at: http:// siteresources.worldbank.org/INTWBIGOVANTCOR/ Resources/florini.pdf (accessed 8 April 2016).

Florini A (ed.) (2007) The Right to Know. Transparency for an Open World. Columbia University Press.

Glencorse B (2013) Liberia ten years on: corruption and accountability remain country's biggest challenges. Available at: http://africanarguments.org/2013/08/16/ liberia-ten-years-on-corruption-and-accountabilityremain-countrys-biggest-challenges-by-blair-glencorse/ (accessed 12 April, 2016).

Gongloe ST (2012) Testing freedom of information in Liberia. A scoping paper on the laws, policy and practice on the right of the people to know versus the protection of national security in Liberia. Available at: https://www.google.se/\#q=Testing +Freedom + of + Information $+\mathrm{in}+$ Liberia $+\mathrm{A}+$ Scoping + Paper + on + the + laws $\% 2 \mathrm{C}+$ policy + and + practice + on + the + right + of + the + people + to + know + versus + the + Protection + of + National + Security + in + Liberia (accessed 5 September 2016).

IBIS (2014) Public Accountability and Civic Engagement (PACE) Program 2014-2017. Available at: http://ibisli beria.org/sites/default/files/media/pdf_global/liberia_ pdf/ibis_liberia_pace_governance_tp.pdf (accessed 10 September 2016).

ILab (2015) Liberia's Open Government Partnership Commitments and Action Plan 2015-2016. Available at: http://ilabliberia.org/wp-content/uploads/2012/01/2015OGP-Action-Plan-proposed-deliverables-April-29-1. pdf (accessed 22 April 2016).

Johnson ES (2010) Post-conflict Liberia: From tragedy to opportunity. Available at: http://www.emansion.gov.lr/ doc/2_19_10_Address_at_University_of_Legon.pdf (accessed 8 April 2016).

Johnston M (n.d.) Good governance: rule of law, transparency, and accountability. Available at: http:// unpan1.un.org/intradoc/groups/public/documents/un/ unpan010193.pdf (accessed 12 April 2016).

Johnston P, Gary BV and David V (2005) The benefits of electronic records management systems. A general review of published and some unpublished cases. Records Management Journal 15:3: 131-140.

Joseph M (2006) Hindrances and prospects of access to information laws. enactment and implementation in Liberia. In Piercing the Veil of Secrecy: Access to Information Monitoring Report. Open Initiative for West Africa.

Joseph M (2014) Liberia: Law implementation and exclusion of access. Available at: http://www.freedominfo .org/2014/10/liberia-law-implementation-exclusionaccess/ (accessed 1 April 2016).

Kpargoi L (2015) International donor relations and the government's access to information policy. Available at: http://www.cima.ned.org/blog/access-to-informa tion-in-liberia/ (accessed 14 April, 2016).

Liberian Government (n.d.) Constitution of the Republic of Liberia. Available at: https://www.unodc.org/tldb/ pdf/Constitution\%20Liberia.pdf (accessed 20 August 2016).

Liberian Government (2010) Liberian Freedom of Information Act. Available at: http://www.liberianembas syus.org/uploads/documents/Liberia $\% 20$ Freedom $\%$ 20of\%20Information\%20Act\%202010x.pdf.

Liberian Government (2013) Open Government Partnership: National Action Plan 2013, Republic of Liberia. Available at: http://www.opengovpartnership.org/node/ 7878/ogp (accessed 13 April, 2016).

Management Study Guide (n.d.) Desk research - methodology and techniques. Available at: http://www.man agementstudyguide.com/desk-research.htm (accessed 2 July 2016).

Manolea B and Cretu V (2013) European public sector information platform. Topic Report No. 2013 /10. The influence of the Open Government Partnership (OGP) on the Open Data discussion. Available at: https://www .europeandataportal.eu/sites/default/files/library/2013 10_the_influence_of_the_ogp_on_the_open_data_dis cussions.pdf (accessed 20 April 2016)

Martini M (2014) Right to information laws: Impact and implementation. Available at: http://www.transparency .org/whatwedo/answer/right_to_information_laws_ impact_and_implementation (accessed 3 April 2016). 
Mayue VA and Kpargoi L (n.d.) Monitoring compliance of the Act to establish freedom of information. Available at:http://www.lmcliberia.org/sites/default/files/Monitoring $\% 20$ Compliance $\% 20$ of\%20the $\% 20$ Freedom $\% 20$ of\% 20Information.pdf (accessed 13 September 2016).

McGee R and Gaventa J (2011) Shifting power? Assessing the impact of transparency and accountability initiatives. Available at: http://www.ids.ac .uk/publication/shifting-power-assessing-the-impact-oftransparency-and-accountability-initiatives (accessed 11 April 2016).

McGee R, Gaventa J, Barrett G, Calland R, Carlitz R, Joshi A and Acosta AM (2010) The impact and effectiveness of transparency and accountability initiatives: A review of the evidence to date. Synthesis report. Available at: http://citeseerx.ist.psu.edu/viewdoc/ download?doi $=10.1 .1 .475 .4323 \&$ rep $=$ rep $1 \&$ type $=$ pd (accessed 9 April 2016).

McGovern M (2005) Rebuilding a failed state: Liberia. Development in Practice 15:6.

Neuman L (2002) Access to information. A key to democracy. Available at: https://www.cartercenter.org/docu ments/1272.pdf (accessed 20 April, 2016).

Ngoepe M (2004) Accountability, transparency and good governance: the National Archives and Records Service of South Africa's role in helping government to better service delivery to the South Africans. Paper presented at the Library and Information Association of South Africa. Available at: https://www.researchgate.net/publi cation/274952383_Accountability_transparency_and_ good_governance_the_National_Archives_and_ Records_Service_of_South_Africa's_role_in_helping government_to_better_service_delivery_to_the_South_ Africans (accessed 12 April 2016).

Organisation for Economic Co-operation and Development (2016) OECD and post-2015 reflections. Building more effective, accountable, and inclusive institutions for all. Element 6:1. Available at: https://www.oecd.org/dac/_ POST-2015\%20effective $\% 20$ and $\% 20$ accountable $\%$ 20institutions.pdf (accessed 12 April 2016).

Radelet S (2007) Reviving economic growth in Liberia. Working paper Number 133. Available at: http://www .cgdev.org/files/14912_file_Liberia_Growth.pdf (accessed 12 September 2013).

Randall L, Kpargoi L and Pulano C (n.d.) Media reach and penetration study. Available at: http://lmc.0fees.net/ PDF/Media-Reach-Penetration-Study-LMC-Zeon.pdf (accessed 12 September 2016).

Reeve R (2011) Sustaining the conversation: Media, information flows and conflict in Liberia. Available at: http:// www.ifp-ew.eu/pdf/201112IfPEWMediaInfoConflictLi beria.pdf (accessed 12 April 2016).

Rich E and Warner TN (2012) Addressing the roots of Liberia's conflict through the Extractive Industries Transparency Initiative. Available at: http://environmen
talpeacebuilding.org/assets/Documents/LibraryItem 000_Doc_096.pdf (accessed 4 April 2016).

Small Arms Survey (2011) Liberia armed violence assessment. Issue Brief. A legacy of war? Perceptions of security in Liberia. (Iss. 1). Available at: https://www.files .ethz.ch/isn/143589/Liberia-AVA-IB1.pdf (accessed 22 August 2016).

Svärd P (2014) Information and Records Management Systems and the Impact of Information Culture on the Management of Public Information. $\mathrm{PhD}$ thesis, University of Amsterdam, Amsterdam. Available at: http://dare .uva.nl/document/2/140656 (accessed 21 April 2016).

Teemu (2013) Open government and freedom of information in Liberia - more than a Hollywood dream? Available at: http://ilabliberia.org/2013/09/ 29/open-government-and-freedom-of-information-inliberia-more-than-hollywood-dream/ (accessed 23 March 2016).

The Carter Centre (2014) Women and the right of access to information in Liberia. Available at: https://www.carter center.org/resources/pdfs/peace/ati/women-and-ati10172014.pdf (accessed 9 September 2016).

The Carter Centre (2016) Findings from select agencies: Liberia. The Carter Center's Acess to Information Legislation Implementation Assessment Tool. Available at: https://www.cartercenter.org/resources/pdfs/peace/ati/ liberia-iat-country-report.pdf (accessed 13 September 2016).

The Carter Centre (n.d.) Access to information in Liberia. Available at: https://www.cartercenter.org/peace/ati/atiin-liberia.html (accessed 10 September 2016).

Treisman L (2014) Access to information: bridging the digital divide in Africa. Available at: http://www.the guardian.com/global-development-professionals-net work/2014/jan/24/digital-divide-access-to-informationafrica (accessed 15 April 2016).

U4 Anti-Corruption Resource Centre (2012). Overview of corruption and anti-corruption in Liberia. Available at: http://www.u4.no/publications/overview-of-corruptionand-anti-corruption-in-liberia/ (accessed 10 September 2016).

Yong SLJ and Cheong YNA (2004) Promoting citizencentered approaches to e-government programmes strategies \& perspectives from Asian economies. Paper presented at the Second APEC High-Level Symposium on e-Government, Acapulco, Mexico. Available at: www.egov-in-asia.com/egov-2/cms .../egov-paper-forapec.pdf (accessed 8 March 2010).

\section{About the author}

Proscovia Svärd is currently a Post-doctoral Research Fellow at the University of South Africa (Unisa) in the School of Interdisciplinary Research and Postgraduate Studies and 
the Department of Information Science. She works as a Senior Lecturer at the Institute of History and Contemporary Studies at the University of Södertörn, Stockholm. She co-ordinates the Nordic Africa Research Network based in Sweden and has earlier worked as an Archivist, Research Administrator for the Program on Post-Conflict Transition, the State and Civil Society and Project-Co-ordinator for a Nordic Documentation Project on the Liberation Struggles in Southern Africa (www.liberationafrica.se) at the Nordic Africa Institute, Uppsala, Sweden. She completed her $\mathrm{PhD}$ at the University of Amsterdam. She has a Licentiate Degree in Data and Systems Sciences, BA and MA in Archives and Information Science from Mid Sweden University and a BSc in Media and Information Science from Uppsala University. Her research interests include; enterprise content management, records management, information culture, e-government development, public sector information (PSI), long-term preservation of digital information, truth and reconciliation commissions and their documentation processes, the role of archives in enhancing accountability and transparency in government institutions, information access and the link to democracy and development. Contact: University of Södertörn, Stockholm. Tel. No. +46 736507333. Email: Proscovia.Svard@sh.se 